\title{
Deinococcus indicus sp. nov., an arsenic-resistant bacterium from an aquifer in West Bengal, India
}

\author{
Correspondence \\ S. Shivaji \\ shivas@ccmb.res.in
}

\author{
K. Suresh, ${ }^{1}$ G. S. N. Reddy, ${ }^{1}$ S. Sengupta ${ }^{2}$ and S. Shivaji ${ }^{1}$ \\ ${ }^{1}$ Centre for Cellular and Molecular Biology, Uppal Road, Hyderabad 500007 , India \\ ${ }^{2}$ Geological Survey of India, GSI Complex, DK-6, Sector-II, Bidhannagar, Kolkata 700091 , India
}

Arsenic contamination of water has been reported in various parts of the world, including India, where arsenic has contaminated the groundwater in the entire Bengal delta, which covers the Indian state of West Bengal and parts of Bangladesh. The source of arsenic in this site has been attributed to both the oxidation of pyrite/arsenopyrite in the aquifer (Bhattacharya et al., 1997) and the reduction of ferrous-coated sand grains (Nickson et al., 1998). Diverse microbial flora that is resistant to arsenic, including Pseudomonas fluorescens (de Vicente et al., 1990; Prithivirajsingh et al., 2001), Bacillus subtilis (Sato \& Kobayashi, 1998), Thermus aquaticus and Thermus thermophilus (Gihring et al., 2001), Yersinia enterocolitica and Yersinia intermedia (Bansal et al., 2000), Streptomyces noursei (Friedrich et al., 1984) and Desulfitobacterium sp. (Niggemyer et al., 2001), has been reported from various habitats.

Published online ahead of print on 12 September 2003 as DOI 10.1099/ijs.0.02758-0.

Abbreviations: DPG, diphosphatidylglycerol; PC, phosphatidylcholine; $\mathrm{PG}$, phosphatidylglycerol; $\mathrm{PI}$, phosphatidylinositol.

The GenBank/EMBL/DDBJ accession number for the 16S rRNA gene sequence of strain $\mathrm{Wt} / 1 \mathrm{a}^{\top}$ is AJ549111.

A table showing survival of Deinococcus species under UV light and a figure showing one-dimensional TLC of total lipid extracts from Deinococcus species are available as supplementary material in IJSEM Online.
Arsenic-contaminated water that was collected in sterile tubes from various aquifers in July 2001, when plated directly onto a nutrient agar plate and incubated at $30{ }^{\circ} \mathrm{C}$ for 2 days, yielded $2 \cdot 21 \times 10^{3}$ c.f.u. $\mathrm{ml}^{-1}$. These colonies represented 13 different morphotypes. Based on protein profiles, these 13 morphotypes were categorized into four groups (data not shown), as follows: group $\mathrm{I}\left(\mathrm{Wt} / 1 \mathrm{a}^{\mathrm{T}}\right.$, $\mathrm{Wt} / 1 \mathrm{~b}$ and $\mathrm{Wt} / 1 \mathrm{c})$; group II $(\mathrm{Wt} / 2 \mathrm{a}, \mathrm{Wt} / 2 \mathrm{~b}, \mathrm{Wt} / 2 \mathrm{c}$ and $\mathrm{Wt} / 2 \mathrm{~d}$ ); group III (Wt/3a, $\mathrm{Wt} / 3 \mathrm{~b}, \mathrm{Wt} / 3 \mathrm{c}, \mathrm{Wt} / 3 \mathrm{~d}$ and $\mathrm{Wt} / 3 \mathrm{e})$; and group IV (Wt/4a and $\mathrm{Wt} / 4 \mathrm{~b})$. All strains within each group had identical protein profiles, indicating that they were clonal in origin. In the present study, isolate $\mathrm{Wt} / 1 \mathrm{a}^{\mathrm{T}}$, which was chosen as a representative strain of the three isolates that belong to group I, is subjected to polyphasic taxonomic studies. This redpigmented bacterium was identified as a novel species of the genus Deinococcus and was assigned the name Deinococcus indicus sp. nov.

Strain $\mathrm{Wt} / 1 \mathrm{a}^{\mathrm{T}}$ was isolated from a shallow aquifer in the Bengal basin, Chakdah district, West Bengal, India $\left(88^{\circ} 35^{\prime} \mathrm{S} 23^{\circ} 3^{\prime} \mathrm{E}\right)$. The medium used for isolation of the bacterium was nutrient agar $[0.5 \%(\mathrm{w} / \mathrm{v})$ peptone, $0.3 \%$ $(\mathrm{w} / \mathrm{v})$ beef extract, $0.5 \% \mathrm{NaCl}$ and $1.5 \%(\mathrm{w} / \mathrm{v})$ agar, $\mathrm{pH}$ 6.5]. Nutrient agar was used for growth, maintenance and biochemical tests. Optimum $\mathrm{pH}$ and temperature for growth were 6.5 and $30^{\circ} \mathrm{C}$, respectively. Cultures were grown in nutrient broth that contained either sodium 
arsenate $\left(\mathrm{Na}_{2} \mathrm{HAsO}_{4}\right)$ or arsenic trioxide $\left(\mathrm{As}_{2} \mathrm{O}_{3}\right)$ to determine the tolerance of the culture to arsenate and arsenite.

The bacterial culture was observed in the lag, exponential and stationary phases of growth under a phase-contrast microscope $(\times 1000)$ to ascertain the shape and motility of the bacterium. Biochemical tests were performed as described by Lanyi (1987), Reddy et al. (2002a, b) and Smibert \& Krieg (1994). Single carbon source assimilation tests were performed in a minimal basal salts medium [which contained $10.5 \mathrm{~g} \mathrm{~K}_{2} \mathrm{HPO}_{4}, 4.5 \mathrm{~g} \mathrm{KH}_{2} \mathrm{PO}_{4}, 1 \mathrm{~g}$ $\left(\mathrm{NH}_{4}\right)_{2} \mathrm{SO}_{4}$ and $15 \mathrm{~g}$ agar (1 medium prepared in distilled water $)^{-1}$. Organic substrates were filter-sterilized (Millipore; catalogue no. PHWP02500) and added to the medium at a final concentration of $5 \mathrm{~g} \mathrm{l}^{-1}$ before plates were poured. The sensitivity of the culture to different antibiotics was checked by using antibiotic discs that were supplied by HiMedia. SDS-PAGE was performed according to the method of Laemmli (1970). Isolation of DNA and determination of its $\mathrm{G}+\mathrm{C}$ content were performed as described previously (Shivaji et al., 1989; Reddy et al., 2000). DNADNA hybridization was performed by the membrane filter method (Tourova \& Antonov, 1987) as described previously (Shivaji et al., 1992; Reddy et al., 2000). To determine tolerance of the culture to UV radiation, the culture was grown to late-exponential phase and harvested at $5000 \mathrm{~g}$ for $5 \mathrm{~min}$ at $4{ }^{\circ} \mathrm{C}$; the cell pellet was suspended in $10 \mathrm{ml}$ phosphate buffer $(\mathrm{pH} 7 \cdot 2)$, diluted serially and $0 \cdot 1 \mathrm{ml}$ was spread on nutrient agar plates. Plates (with their lids open) were then exposed to UV light $(\mathrm{UV}-\mathrm{B}, 15 \mathrm{~W} \times 4$; Sanyo Denki) at a distance of $30 \mathrm{~cm}$ from the UV source for the required dose and were incubated subsequently at $30^{\circ} \mathrm{C}$ for 5 days. The UV dose was monitored with a model RX003 UV detector (UVI Tech). Deinococcus radiodurans DSM $20539^{\mathrm{T}}, D$. grandis IAM $13005^{\mathrm{T}}$ and Escherichia coli DH5 $\alpha$ were used as controls to evaluate the effect of UV radiation on the growth of the micro-organisms.

Cells were grown in nutrient broth at $30^{\circ} \mathrm{C}$ and the fatty acid methyl esters (Sato \& Murata, 1988) were analysed as described previously (Reddy et al., 2002a). Isoprenoid quinones were extracted, separated by HPLC and identified as described previously (Reddy et al., 2003). Peptidoglycan was prepared and analysed according to the method described by Komagata \& Suzuki (1987). Polar lipids were extracted and analysed according to the method described by Counsell \& Murray (1986). In this method, the bacterial cell pellet is extracted with chloroform:methanol $(2: 1)$ and separated by one-dimensional TLC, using a precoated silica gel TLC plate (Merck; catalogue no. 5721) and chloroform:acetone:methanol:acetic acid: water $(10: 4: 2: 2: 1, \mathrm{v} / \mathrm{v})$ as the solvent system. Total lipids were detected by spraying with $25 \% \mathrm{H}_{2} \mathrm{SO}_{4}$ in ethanol, followed by charring at $150{ }^{\circ} \mathrm{C}$ for $5 \mathrm{~min}$ and compared with phosphatidylinositol (PI), phosphatidylcholine (PC), phosphatidylglycerol (PG) and diphosphatidylglycerol (DPG), which were run under similar conditions. Phosphoglycolipids were detected by staining with $\alpha$-naphthol [a mixture of $10.5 \mathrm{ml} 15 \%(\mathrm{w} / \mathrm{v}) \alpha$-naphthol in ethanol, $6.5 \mathrm{ml}$ concentrated $\mathrm{H}_{2} \mathrm{SO}_{4}$ and $4.0 \mathrm{ml}$ water], whereas ninhydrin $(0.25 \%$ in acetone) was used to detect aminoglycolipids.

The 16S rRNA gene was amplified (Shivaji et al., 2000), purified with a QIAquick PCR purification kit (Qiagen) and sequenced by using an ABI PRISM BigDye Terminator cycle sequencing kit and an automatic DNA sequencer (ABI PRISM model 3700) (both from Applied Biosystems). The partial 16S rDNA sequence (1456 bp) was aligned with those of species of the genera Deinococcus, Kocuria and Arthrobacter by using CLUSTAL W (Thompson et al., 1994). Pairwise evolutionary distances were computed by using the DNADIST program with the Kimura two-parameter model, as developed by Kimura (1980). Phylogenetic trees were constructed by using two tree-making algorithms: UPGMA and parsimony (DNAPARS; Felsenstein, 1993). Stability among the clades of a phylogenetic tree was assessed by taking 1000 replicates of the dataset, which were analysed by using the programs SEQBOOT, DNADIST, NEIGHBOR (UPGMA algorithm) and CONSENSE of the PHYLIP package.

Cells of $\mathrm{Wt} / 1 \mathrm{a}^{\mathrm{T}}$ stain Gram-negative and are rod-shaped, non-motile, non-sporulating and red-pigmented. Cell-wall peptidoglycan contains ornithine as the diamino acid (A3 $\beta$ variant), MK-8 is the organism's major respiratory quinone, $\mathrm{C}_{15: 1}$ and $\mathrm{C}_{16: 1}$ are the major fatty acids and the DNA G $+\mathrm{C}$ content is $65 \cdot 8 \mathrm{~mol} \%$. Based on the above characteristics, strain $\mathrm{Wt} / 1 \mathrm{a}^{\mathrm{T}}$ was identified as a member of the genus Deinococcus (Murray \& Brooks, 1986; Rainey et al., 1997). A BLAST sequence similarity search and phylogenetic studies corroborated the above data and confirmed that strain $\mathrm{Wt} / 1 \mathrm{a}^{\mathrm{T}}$ belongs to the genus Deinococcus. Furthermore, the 16S rRNA gene sequence of strain $\mathrm{Wt} /$ $1 \mathrm{a}^{\mathrm{T}}$ possessed all the signature nucleotides, namely $\mathrm{C}, \mathrm{G}, \mathrm{T}$, G, T, A, G, C and C at positions 657, 749, 757, 1050, 1208, $1421,1429,1471$ and 1479, respectively, that are characteristic features of the genus Deinococcus (Rainey et al., 1997).

Phylogenetic analysis based on the 16S rRNA gene sequence indicated that strain $\mathrm{Wt} / 1 \mathrm{a}^{\mathrm{T}}$ is related closely to $D$. grandis IAM $13005^{\mathrm{T}}$ (Oyaizu et al., 1987; Rainey et al., 1997), with $95 \%$ sequence similarity. The topology of the phylogenetic tree (Fig. 1) indicated that strain $\mathrm{Wt} / 1 \mathrm{a}^{\mathrm{T}}$ forms a robust clade with $D$. grandis IAM $13005^{\mathrm{T}}$, with a bootstrap resampling value of $100 \%$. Furthermore, the phylogenetic affiliation of strain $\mathrm{Wt} / 1 \mathrm{a}^{\mathrm{T}}$ with $D$. grandis IAM $13005^{\mathrm{T}}$ is confirmed by its rod shape and Gram-staining (both isolates stain Gram-negative), whereas other species of the genus are Gram-positive and spherical in shape. However, when the $16 \mathrm{~S}$ rRNA gene sequence of strain $\mathrm{Wt} / 1 \mathrm{a}^{\mathrm{T}}(1453 \mathrm{bp})$ is compared with that of $D$. grandis IAM $13005^{\mathrm{T}}, 73$ bases were observed to be different and strain $\mathrm{Wt} / 1 \mathrm{a}^{\mathrm{T}}$ shared only $14 \%$ DNA-DNA reassociation with $D$. grandis IAM $13005^{\mathrm{T}}$. Furthermore, strain $\mathrm{Wt} / 1 \mathrm{a}^{\mathrm{T}}$ showed low $16 \mathrm{~S}$ rRNA gene sequence similarity values of $91 \cdot 94,91 \cdot 67,93 \cdot 51,91 \cdot 6$, 89.39 and $91.5 \%$ with Deinococcus radiopugnans, Deinococcus murrayi, D. radiodurans, Deinococcus radiophilus, 


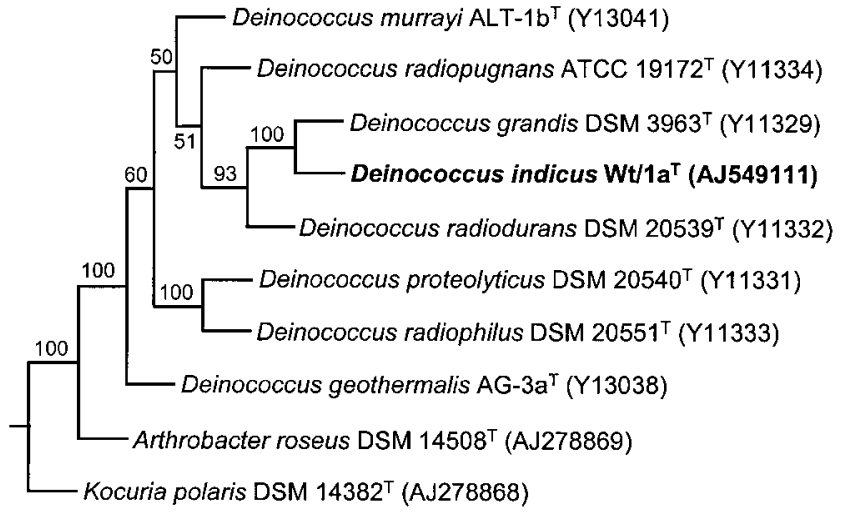

Fig. 1. UPGMA phenogram showing the phylogenetic relationship between Deinococcus indicus $\mathrm{Wt} / 1 \mathrm{a}^{\mathrm{T}}$, other species of the genus Deinococcus and related reference micro-organisms, based on 16S rRNA gene sequence analysis. Bootstrap values are given at nodes. Branch-lengths in the phenogram are not to scale.

Deinococcus geothermalis and Deinococcus proteolyticus, respectively.

Strain $\mathrm{Wt} / 1 \mathrm{a}^{\mathrm{T}}$ also differed from $D$. grandis IAM $13005^{\mathrm{T}}$ with respect to a number of physiological characteristics (Table 1). It had higher amounts of the fatty acids $C_{16: 0}$ and $\mathrm{C}_{16: 1}$ and reduced amounts of $\mathrm{C}_{14: 0}$ and $\mathrm{C}_{15: 1}$ (Table 2). In addition, lipid analysis indicated that strain $\mathrm{Wt} / 1 \mathrm{a}^{\mathrm{T}}$ had seven lipids with $R_{\mathrm{f}}$ values of $0 \cdot 21,0 \cdot 27,0 \cdot 42$, $0 \cdot 70,0 \cdot 76,0.84$ and 0.89 (identical to the lipid profile of $D$. grandis IAM $13005^{\mathrm{T}}$ ), but differed in that it did not contain lipids $1-3$, with $R_{\mathrm{f}}$ values of $0 \cdot 11,0 \cdot 12$ and $0 \cdot 17$, respectively, as observed in D. grandis IAM $13005^{\mathrm{T}}$ (see Supplementary Figure, available in IJSEM Online). Furthermore, none of the lipids matched with PI, PC, PG or DPG, although one of the phosphoglycolipids (lipid 4 , with an $R_{\mathrm{f}}$ value of 0.21 ) showed similar (but not identical) chromatographic behaviour to PI. The fact that lipid 4 and PI are different is also evident from the fact that unlike lipid 4, which stains positively with $\alpha$-naphthol, PI does not stain [see Supplementary Fig. (B), available in IJSEM Online]. In addition to the above differences, strain $\mathrm{Wt} / 1 \mathrm{a}^{\mathrm{T}}$ grew in the presence of 10 and $0 \cdot 2 \mathrm{mM}$ arsenate and arsenite, respectively, whereas D. grandis IAM $13005^{\mathrm{T}}$ is highly sensitive to both arsenate and arsenite (Table 1). Cultures of D. radiodurans DSM 20539 ${ }^{\mathrm{T}}, D$. grandis IAM $13005^{\mathrm{T}}$ and strain $\mathrm{Wt} / 1 \mathrm{a}^{\mathrm{T}}$ were found to be more resistant to UV radiation than E. coli $\mathrm{DH} 5 \alpha$. When the cultures were exposed to varying doses of UV radiation, it was observed that the survival of E. coli decreased by $99 \%$ when exposed to $0.32 \mathrm{~J} \mathrm{~cm}^{-2}$, whereas at the same dose, survival in strain $\mathrm{Wt} / 1 \mathrm{a}^{\mathrm{T}}, D$. grandis IAM $13005^{\mathrm{T}}$ and D. radiodurans DSM $20539^{\mathrm{T}}$ was 66,81 and $85 \%$, respectively. At higher UV doses, E. coli DH5 $\alpha$ did not survive, but $2-4 \%$ survival was observed in the remaining three cultures, even when they were exposed to $5.87 \mathrm{~J} \mathrm{~cm}^{-2}$ (see
Table 1. Phenotypic differences between $D$. indicus $\mathrm{Wt} / 1 \mathrm{a}^{\top}$ and $D$. grandis IAM $13005^{\top}$

Taxa: 1, D. indicus $\mathrm{Wt} / 1 \mathrm{a}^{\mathrm{T}} ; 2$, D. grandis IAM $13005^{\mathrm{T}}$. Cells were cultured in appropriate media at $30^{\circ} \mathrm{C}$ for all studies. Both species are resistant to $1 \mathrm{mM} \mathrm{Na} \mathrm{NAsO}_{4}$. +, Positive; -, negative; $\mathrm{R}$, resistant; $\mathrm{S}$, sensitive.

\begin{tabular}{|c|c|c|}
\hline Characteristic & 1 & 2 \\
\hline \multicolumn{3}{|l|}{ Resistance to arsenic: } \\
\hline \multicolumn{3}{|l|}{$\mathrm{As}(\mathrm{V})\left(\mathrm{Na}_{2} \mathrm{HAsO}_{4}\right):$} \\
\hline $5 \mathrm{mM}$ & + & - \\
\hline $10 \mathrm{mM}$ & + & - \\
\hline $\mathrm{As}(\mathrm{III})\left(\mathrm{As}_{2} \mathrm{O}_{3}\right)(0 \cdot 2 \mathrm{mM})$ & + & - \\
\hline \multicolumn{3}{|l|}{ Biochemical characteristics: } \\
\hline Arginine dihydrolase & + & - \\
\hline Triple sugar/iron agar (change to yellow) & + & - \\
\hline \multicolumn{3}{|l|}{ Utilization as carbon source: } \\
\hline L-Arabinose & + & - \\
\hline D-Cellobiose & + & - \\
\hline Lactose & + & - \\
\hline D-Mannose & + & - \\
\hline D-Melibiose & + & - \\
\hline L-Rhamnose & + & - \\
\hline D-Raffinose & + & - \\
\hline L-Tryptophan & + & - \\
\hline L-Aspartic acid & + & - \\
\hline L-Arginine & + & - \\
\hline L-Histidine & + & - \\
\hline \multicolumn{3}{|l|}{ Sensitivity to antibiotics: } \\
\hline Amoxycillin & $\mathrm{R}$ & $\mathrm{S}$ \\
\hline Ampicillin & $\mathrm{R}$ & $\mathrm{S}$ \\
\hline Nalidixic acid & $\mathrm{S}$ & $\mathrm{R}$ \\
\hline \multicolumn{3}{|l|}{ Chemotaxonomic characteristics: } \\
\hline Lipid $1\left(R_{\mathrm{f}}\right.$ value, $\left.0 \cdot 11\right)$ & - & + \\
\hline Lipid $2\left(R_{\mathrm{f}}\right.$ value, $\left.0 \cdot 12\right)$ & - & + \\
\hline Lipid $3\left(R_{\mathrm{f}}\right.$ value, $\left.0 \cdot 17\right)$ & - & + \\
\hline
\end{tabular}

Supplementary Table in IJSEM Online). Thus, based on physiological, chemotaxonomic and phylogenetic differences, it is proposed to assign novel species status to strain $\mathrm{Wt} / 1 \mathrm{a}^{\mathrm{T}}$, for which the name Deinococcus indicus sp. nov. is proposed, with $\mathrm{Wt} / 1 \mathrm{a}^{\mathrm{T}}\left(=\right.$ MTCC $\left.4913^{\mathrm{T}}=\mathrm{DSM} 15307^{\mathrm{T}}\right)$ as the type strain.

\section{Description of Deinococcus indicus sp. nov.}

Deinococcus indicus (in'di.cus. L. masc. adj. indicus pertaining to India, Indian).

Cells stain Gram-negative and are non-motile and rodshaped. Colonies on nutrient agar medium are redpigmented, smooth, convex, circular, uniform-edged and 1-2 $\mathrm{mm}$ in diameter. Optimum growth occurs at $30^{\circ} \mathrm{C}$; growth occurs at $20-37^{\circ} \mathrm{C}$ and $\mathrm{pH} 6-7$. Tolerates up to $1.0 \% \mathrm{NaCl}$ and is resistant to $\mathrm{UV}$ radiation $\left(5.87 \mathrm{~J} \mathrm{~cm}^{-2}\right)$. Strictly aerobic and positive for catalase, gelatinase, amylase, arginine dihydrolase, aesculin and casein hydrolysis and 
Table 2. Fatty acid composition (\%) of $D$. indicus $\mathrm{Wt} / 1 \mathrm{a}^{\top}$ and D. grandis IAM $13005^{\mathrm{T}}$

Taxa: 1, D. indicus $\mathrm{Wt} / 1 \mathrm{a}^{\mathrm{T}} ; 2$, D. grandis IAM $13005^{\mathrm{T}}$. Cultures were grown in nutrient broth at $30{ }^{\circ} \mathrm{C}$ and used for analysis of fatty acid methyl esters. -, Absent.

\begin{tabular}{|lcc|}
\hline Fatty acid & $\mathbf{1}$ & $\mathbf{2}$ \\
\hline Straight-chain: & & \\
$\mathrm{C}_{14: 0}$ & $1 \cdot 93$ & $3 \cdot 85$ \\
$\mathrm{C}_{16: 0}$ & $12 \cdot 15$ & $7 \cdot 21$ \\
$\mathrm{C}_{18: 0}$ & $0 \cdot 08$ & - \\
Branched-chain: & & \\
iso-C $15: 0$ & $0 \cdot 06$ & $0 \cdot 18$ \\
anteiso-C & $4 \cdot 78$ & $4 \cdot 82$ \\
anteiso- $\mathrm{C}_{17: 0}$ & $9 \cdot 77$ & $10 \cdot 52$ \\
Unsaturated: & & \\
$\mathrm{C}_{15: 1}$ & $12 \cdot 45$ & $22 \cdot 44$ \\
$\mathrm{C}_{16: 1}$ & $33 \cdot 65$ & $19 \cdot 56$ \\
$\mathrm{C}_{17: 1}$ & $10 \cdot 7$ & $11 \cdot 29$ \\
$\mathrm{C}_{18: 1}$ & $0 \cdot 26$ & $0 \cdot 24$ \\
\hline
\end{tabular}

reduction of nitrate to nitrite, but negative for oxidase, lipase, urease, indole production, Voges-Proskauer test and citrate utilization. A number of compounds are utilized as sole carbon sources (Table 1), including D-maltose, sucrose, D-ribose and L-tyrosine, but not acetate, cellulose, D-fructose, D-galactose, D-glucose, meso-inositol, pyruvate, D-sorbose, L-glycine, creatinine, L-alanine or L-cysteine. Sensitive to the antibiotics bacitracin, chloramphenicol, kanamycin, nalidixic acid, neomycin, penicillin, rifampicin, rifamycin, streptomycin and tetracycline, but resistant to ampicillin and amoxycillin. Fatty acid composition of the type strain is given in Table 2; there are seven unknown polar lipids. Major respiratory quinone is MK-8 and cellwall peptidoglycan contains ornithine as the diamino acid. DNA G $+\mathrm{C}$ content is $65 \cdot 8 \mathrm{~mol} \%$.

The type strain is $\mathrm{Wt} / 1 \mathrm{a}^{\mathrm{T}}\left(=\right.$ MTCC $\left.4913^{\mathrm{T}}=\operatorname{DSMZ} 1537^{\mathrm{T}}\right)$.

\section{Acknowledgements}

This work was supported by a grant from the Department of Biotechnology, Government of India, New Delhi, India.

\section{References}

Bansal, N., Sinha, I. \& Virdi, J. S. (2000). Arsenic and cadmium resistance in environmental isolates of Yersinia enterocolitica and Yersinia intermedia. Can J Microbiol 46, 481-484.

Bhattacharya, P., Chatterjee, D. \& Jacks, G. (1997). Occurrence of arsenic-contaminated groundwater in alluvial aquifers from Delta Plains, eastern India: options for safe drinking water supply. Int J Water Resour Dev 13, 79-92.

Counsell, T. J. \& Murray, R. G. E. (1986). Polar lipid profiles of the genus Deinococcus. Int J Syst Bacteriol 36, 202-206.

de Vicente, A., Avilès, M., Codina, J. C., Borrego, J. J. \& Romero, P. (1990). Resistance to antibiotics and heavy metals of Pseudomonas aeruginosa isolated from natural waters. J Appl Bacteriol 68, 625-632.
Felsenstein, J. (1993). PHYLIP (phylogeny inference package), version $3.5 \mathrm{c}$. Department of Genetics, University of Washington, Seattle, USA.

Friedrich, W., Bormann, E. J. \& Grafe, U. (1984). Isolation and biological properties of arsenate-resistant strains of Streptomyces noursei. Z Allg Mikrobiol 24, 13-19.

Gihring, T. M., Druschel, G. K., McCleskey, R. B., Hamers, R. J. \& Banfield, J. F. (2001). Rapid arsenite oxidation by Thermus aquaticus and Thermus thermophilus: field and laboratory investigations. Environ Sci Technol 35, 3857-3862.

Kimura, M. (1980). A simple method for estimating evolutionary rates of base substitutions through comparative studies of nucleotide sequences. J Mol Evol 16, 111-120.

Komagata, K. \& Suzuki, K. (1987). Lipid and cell wall analysis in bacterial systematics. Methods Microbiol 19, 161-206.

Laemmli, U. K. (1970). Cleavage of structural proteins during the assembly of the head of bacteriophage T4. Nature 227, 680-685.

Lanyi, B. (1987). Classical and rapid identification methods for medically important bacteria. Methods Microbiol 19, 1-67.

Murray, R. G. E. \& Brooks, B. W. (1986). Genus I. Deinococcus Brooks and Murray 1981, 354 ${ }^{\mathrm{VP}}$. In Bergey's Manual of Systematic Bacteriology, vol. 2, pp. 1035-1043. Edited by P. H. A. Sneath, N. S. Mair, M. E. Sharpe \& J. G. Holt. Baltimore: Williams \& Wilkins.

Nickson, R., McArthur, J., Burgess, W., Ahmed, K. M., Ravenscroft, P. \& Rahman, M. (1998). Arsenic poisoning of Bangladesh groundwater. Nature 395, 338.

Niggemyer, A., Spring, S., Stackebrandt, E. \& Rosenzweig, R. F. (2001). Isolation and characterization of a novel As(V)-reducing bacterium: implications for arsenic mobilization and the genus Desulfitobacterium. Appl Environ Microbiol 67, 5568-5580.

Oyaizu, H., Stackebrandt, E., Schleifer, K. H., Ludwig, W., Pohla, H., Ito, H., Hirata, A., Oyaizu, Y. \& Komagata, K. (1987). A radiationresistant rod-shaped bacterium, Deinobacter grandis gen. nov., sp. nov., with peptidoglycan containing ornithine. Int $J$ Syst Bacteriol 37, 62-67.

Prithivirajsingh, S., Mishra, S. K. \& Mahadevan, A. (2001). Detection and analysis of chromosomal arsenic resistance in Pseudomonas fluorescens strain MSP3. Biochem Biophys Res Commun 280, 1393-1401.

Rainey, F. A., Nobre, M. F., Schumann, P., Stackebrandt, E. \& Da Costa, M. S. (1997). Phylogenetic diversity of the deinococci as determined by $16 \mathrm{~S}$ ribosomal DNA sequence comparison. Int J Syst Bacteriol 47, 510-514.

Reddy, G. S. N., Aggarwal, R. K., Matsumoto, G. I. \& Shivaji, S. (2000). Arthrobacter flavus sp. nov., a psychrophilic bacterium isolated from a pond in McMurdo Dry Valley, Antarctica. Int J Syst Evol Microbiol 50, 1553-1561.

Reddy, G. S. N., Prakash, J. S. S., Matsumoto, G. I., Stackebrandt, E. \& Shivaji, S. (2002a). Arthrobacter roseus sp. nov. a psychrophilic bacterium isolated from an Antarctic cyanobacterial mat sample. Int J Syst Evol Microbiol 52, 1017-1021.

Reddy, G. S. N., Prakash, J. S. S., Vairamani, M., Prabhakar, S., Matsumoto, G. I. \& Shivaji, S. (2002b). Planococcus antarcticus and Planococcus psychrophilus spp. nov. isolated from cyanobacterial mat samples collected from ponds in Antarctica. Extremophiles 6, 253-261.

Reddy, G. S. N., Matsumoto, G. I. \& Shivaji, S. (2003). Sporosarcina macmurdoensis sp. nov., from a cyanobacterial mat sample from a pond in the McMurdo Dry Valleys, Antarctica. Int J Syst Evol Microbiol 53, 1363-1367.

Sato, N. S. \& Murata, N. (1988). Membrane lipids. Methods Enzymol $167,251-259$. 
Sato, T. \& Kobayashi, Y. (1998). The ars operon in the skin element of Bacillus subtilis confers resistance to arsenate and arsenite. J Bacteriol 180, 1655-1661.

Shivaji, S., Rao, N. S., Saisree, L., Reddy, G. S. N., Seshu Kumar, G. \& Bhargava, P. M. (1989). Isolates of Arthrobacter from the soils of Schirmacher Oasis, Antarctica. Polar Biol 10, 225-229.

Shivaji, S., Ray, M. K., Rao, N. S., Saisree, L., Jagannadham, M. V., Seshu Kumar, G., Reddy, G. S. N. \& Bhargava, P. M. (1992). Sphingobacterium antarcticus sp. nov., a psychrotrophic bacterium from the soils of Schirmacher Oasis, Antarctica. Int J Syst Bacteriol 42, 102-106.

Shivaji, S., Vijaya Bhanu, N. \& Aggarwal, R. K. (2000). Identification of Yersinia pestis as the causative organism of plague in India as determined by $16 \mathrm{~S}$ rDNA sequencing and RAPD-based genomic fingerprinting. FEMS Microbiol Lett 189, 247-252.

Smibert, R. M. \& Krieg, N. R. (1994). Phenotypic characterization. In Methods for General and Molecular Bacteriology, pp. 607-655. Edited by P. Gerhardt, R. G. E. Murray, W. A. Wood \& N. R. Krieg. Washington, DC: American Society for Microbiology.

Thompson, J. D., Higgins, D. G. \& Gibson, T. J. (1994). CLUSTAL W: improving the sensitivity of progressive multiple sequence alignment through sequence weighting, position-specific gap penalties and weight matrix choice. Nucleic Acids Res 22, 4673-4680.

Tourova, T. P. \& Antonov, A. S. (1987). Identification of microorganisms by rapid DNA-DNA hybridisation. Methods Microbiol 19, 333-355. 